\title{
PENGEMBANGAN MULTIMEDIA INTERAKTIF BERBASIS PENDEKATAN SAINTIFIK PADA MATERI BANGUN DATAR UNTUK SISWA KELAS IV SEKOLAH DASAR
}

\author{
Development of Interactive Multimedia Based on \\ Scientific Approach on Plane Shape Material \\ for The Fourth Grade Elementary School Students
}

\author{
Akmal Rijal $^{1)}$ Feni Malinda ${ }^{2)}$ \\ ${ }^{1}$ STKIP PGRI Lubuklinggau, Lubuklinggau, Sumatera Selatan, akmalrijal3@gmail.com \\ ${ }^{2}$ STKIP PGRI Lubuklinggau, Lubuklinggau, Sumatera Selatan, fenimalinda12@gmail.com
}

\begin{abstract}
This study aims to produce interactive multimedia based on scientific approach on plane shape material for the fourth grade elementary school students. This is a research and development using a 4-D model consisting of 4 stages, namely: defining, designing, developing, and disseminating. This research data collection technique is based on the results of the assessment by three experts, namely: expert on material, expert on media, and linguists. The expert's assessment shows that interactive multimedia meets the eligibility criteria. At the product feasibility test stage in a small group consisting of nine students, it was found that interactive multimedia met the eligibility criteria with an average score of 3.01 with a maximum score of 4.0. Based on the results of the study, it can be concluded that the interactive multimedia design based on the scientific approach developed in this study is proven to be feasible and can be used for fourth grade elementary school students.
\end{abstract}

Keywords: plane shape, interactive multimedia, scientific approaches.

\begin{abstract}
ABSTRAK
Penelitian ini bertujuan untuk menghasilkan multimedia interaktif berbasis pendekatan saintifik pada materi bangun datar untuk siswa kelas IV sekolah dasar. Penelitian ini merupakan penelitian dan pengembangan dengan menggunakan model 4-D yang terdiri dari 4 tahap yaitu: tahap pendefinisian (Define), perancangan (Design), pengembangan (Develop) dan penyebaran (Disseminate). Teknik pengumpulan data penelitian ini berdasarkan hasil penilaian oleh ketiga ahli yaitu: ahli materi, ahli media, dan ahli bahasa. Penilaian ahli menunjukkan bahwa multimedia interaktif memenuhi kriteria layak. Pada tahap uji kelayakan produk pada kelompok kecil yang terdiri dari 9 siswa diperoleh bahwa multimedia interaktif memenuhi kriteria layak dengan rata-rata skor 3,01 dengan skor maksimum 4,0. Berdasarkan hasil penelitian dapat disimpulkan bahwa desain multimedia interaktif berbasis pendekatan saintifik yang dikembangkan dalam penelitian ini terbukti layak dan dapat digunakan bagi siswa kelas IV sekolah dasar.
\end{abstract}

Kata kunci: bangun datar, multimedia interaktif, pendekatan saintifik.

\section{PENDAHULUAN}

Perkembangan teknologi telah mengalami kemajuan yang sangat cepat, teknologi telah memberikan pengaruh yang cukup besar terhadap kehidupan manusia dalam berbagai aspek kehidupan. Daryanto dan Karim (2017:5) menyampaikan manfaat teknologi pada bidang pendidikan di abad 21 dapat dilihat dari informasi dan komunikasi dalam segala aspek kehidupan termasuk dalam proses pembelajaran. Tugas guru bukan sekedar mengajar, namun juga harus memanajemen kelas dan mampu menciptakan kelas belajar yang kondusif, kreatif, aktif, dan inovatif dengan menggunakan media sebagai perantara. Proses pembelajaran matematika seharusnya mengandung keempat aspek tersebut. Matematika harus diajarkan kepada anak didik pada semua tingkatan pendidikan untuk membekali siswa dengan kemampuan berpikir kritis, kreatif, sistematis, analitis, dan logis, serta kemampuan dalam bekerja sama (Mashuri, 2019:1). Menurut Musfiqon dan Nurdyansyah (2015:49) pendekatan ilmiah atau scientific approach pada pelaksanaan pembelajaran menjadi bahan perhatian para pendidik akhir-akhir ini, terutama kurikulum 2013 karena mengembangkan kemandirian siswa 
dalam belajar. Menurut Mulyono, dkk. (2018:201) kemandirian belajar merupakan hal yang penting karena dapat memberikan kebebasan siswa dalam belajar, menggunakan langkah mereka sendiri, mengeksplorasi minat pribadi mereka, dan mengembangkan bakat mereka dengan menggunakan kecerdasan ganda sesuai yang mereka sukai. Tantangan ini memerlukan peningkatan keterampilan pendekatan saintifik sebagaimana dimaksudkan juga meliputi mengamati, menanya, mencoba, menalar, dan menyimpulkan (mengkomunikasikan) yang digunakan untuk meningkatkan kreativitas peserta didik, namun kenyataannya guru masih menggunakan metode ceramah konvensional tanpa memanfaatkan media pembelajaran yang ada.

Penggunaan media pembelajaran yang tepat, akan membantu mengurangi masalah pembelajaran yang dihadapi. Pemilihan media pembelajaran yang tepat harus dipilih berdasarkan karakteristik peserta didik. Menurut Sumantri dan Syaodih (2009: 6.3-6.4) karakteristik anak usia sekolah dasar adalah (1) senang bermain, (2) senang bergerak, (3) senang bekerja dalam kelompok, dan (4) senang merasakan atau melakukan/meragakan sesuatu secara langsung. Selanjutnya Susilo (dalam Dewi 2015:8) materi belajar akan bermakna jika siswa mempelajari materi pelajaran yang disajikan memiliki konteks pada siswa sehingga pembelajaran memiliki arti sekaligus menyenangkan. Oleh karena itu materi dengan media yang digunakan pada pembelajaran harus dikembangkan dengan baik agar berfungsi optimal jika sesuai dengan sasaran.

Hal ini juga diperkuat dengan temuan di lapangan melalui hasil observasi dan wawancara dengan guru kelas IV Sekolah Dasar Negeri 5 Kota Lubuklinggau pada pembelajaran matematika bahwa proses pembelajaran matematika masih didominasi oleh guru dengan model pembelajaran konvensional dan media yang digunakan guru selama ini hanya menggunakan bahan ajar cetak dan media pembelajaran yang tidak konkret atau kontekstual. Kemudian fasilitas yang ada di sekolah saperti LCD belum dimaksimalkan untuk proses belajar matematika. Siswa membutuhkan penjelasan dari guru berbentuk nyata, tetapi guru tidak menggunakan media pembelajaran yang menarik perhatian siswa, maka hasil belajar siswa belum maksimal. Kemudian juga diperoleh informasi bahwa multimedia interaktif belum digunakan di Sekolah Dasar Negeri 5 Kota Lubuklinggau.

Berdasarkan hasil penelitian Egok dan Hajani (2018) terbukti bahwa penggunaan multimedia interaktif memiliki efek potensial terhadap hasil belajar siswa dalam pembelajaran IPA di sekolah dasar dengan berada dalam kategori layak dan dapat digunakan. Berdasarkan informasi dari latar belakang dan penelitian terdahulu bahwa multimedia interaktif pada pembelajaran matematika dengan pendekatan saintifik bagi siswa sekolah dasar belum pernah dilakukan. Oleh karena itu penelitian ini difokuskan pada pengembangan multimedia interaktif berbasis pendekatan saintifik pada materi bangun datar untuk siswa kelas IV sekolah dasar.

\section{METODE}

Dalam penelitian ini, peneliti menggunakan metode Research and Development (R\&D). Penelitian ini menghasilkan produk multimedia interaktif dengan menggunakan pendekatan saintifik tentang materi bangun datar. Adapun desain dan pengembangan multimedia interaktif menggunakan model pengembangan 4-D yang terdiri atas 4 tahapan yaitu: define, design, develop, dan disseminate (Sugiyono, 2017). Dalam penelitian ini subjek yang diteliti adalah siswa kelas IV di SD Negeri 5 Lubuklinggau yang berjumlah 9 orang siswa pada materi bangun datar yaitu semester genap tahun ajaran 2020/2021. Data diperoleh dari uji kelayakan dan kegunaan. Hasil dari penilaian instrumen angket ahli materi, ahli media dan ahli bahasa dijadikan sebagai pedoman untuk melakukan revisi. Penyusunan instrumen digunakan untuk menilai multimedia interaktif berbasis pendekatan saintifik mengacu pada pedoman/kisi-kisi instrumen validasi oleh para ahli. Pada instrumen yang disediakan, skor yang digunakan 4, 3, 2, dan 1 yang masing-masing menunjukkan penilaian sangat setuju, setuju, tidak setuju dan sangat tidak setuju. Penilaian kelayakan multimedia interaktif diperoleh dari penilaian angket untuk ahli yang terdiri dari tiga macam yaitu untuk ahli materi, bahasa dan media yang terdiri dari butir-butir pernyataan yang berbeda. Hasil penilaian instrumen dijadikan sebagai pedoman dalam melakukan revisi. Lembar penilaian instrumen respons siswa dan guru akan digunakan untuk menentukan kegunaan produk berupa multimedia interaktif berbasis pendekatan 
saintifik yang dikembangkan. Data yang terkumpul dianalisis secara deskriptif (Rijal, A., dan Egok, A.S., 2019).

\section{HASIL DAN PEMBAHASAN}

\section{Hasil}

Hasil penelitian pengembangan ini adalah sebuah produk multimedia interaktif berbasis pendekatan saintifik pada materi bangun datar untuk siswa kelas IV sekolah dasar. Penelitian ini melalui tahapan agar multimedia interaktif berbasis pendekatan saintifik pada materi bangun datar yang diuji cobakan pada siswa kelas IV sekolah dasar dapat memiliki kelayakan dan kegunaan. Tahap penelitian yang dikembangkan dari metode 4D yang telah dimodifikasi menjadi 3D. Tahapan penelitian pengembangan terdiri dari tahap Define, Design, dan Develop.

Tahap pendefinisian dilakukan melalui analisis awal yaitu masalah dasar pada pembelajaran matematika, kurikulum dan pendekatan yang digunakan. Di samping itu ditemukan fakta bahwa guru belum pernah menggunakan dan mengembangkan multimedia interaktif dalam proses pembelajaran. Berdasarkan observasi dan wawancara yang dilakukan pada kegiatan pembelajaran matematika ditemukan masalah, antara lain yaitu: siswa kurang memperhatikan pembelajaran, siswa kurang terlibat aktif dalam proses pembelajaran, masih didominasi oleh guru dan hanya menggunakan bahan ajar cetak sedangkan fasilitas yang ada di sekolah seperti LCD belum dimaksimalkan untuk kegiatan pembelajaran. Tahap perancangan mempunyai tujuan untuk menghasilkan prototipe pertama dari produk multimedia interaktif. Pada tahap pengembangan diperoleh hasil meliputi: (a) validasi dari ahli materi yang dilakukan oleh Suartini, M.Pd. yang merupakan ahli materi bangun datar; (b) validasi ahli media yang dilakukan oleh Leo Charli, M.Pd. yang merupakan ahli media pembelajaran; (c) validasi ahli bahasa yang dilakukan oleh Dr. Rusmana Dewi, M.Pd yang merupakan ahli bahasa. (d) uji coba kelas kecil dilakukan untuk melihat kepraktisan multimedia interaktif pada siswa kelas IV SD Negeri 5 Lubuklinggau dengan jumlah peserta 9 orang siswa.

Berdasarkan validasi ahli materi multimedia interaktif berbasis pendekatan saintifik pada materi bangun datar analisis kelayakan berdasarkan data pengisian oleh validator materi menunjukkan prototipe pertama multimedia interaktif berbasis pendekatan saintifik yang telah diperbaiki berdasarkan perhitungan dengan skor rata-rata 3,18 dengan kriteria layak. Berdasarkan validasi ahli media, multimedia interaktif berbasis pendekatan saintifik pada materi bangun datar yang diperoleh berdasarkan data pengisian angket oleh validator media menunjukkan bahwa prototipe pertama multimedia interktif berbasis pendekatan saintifik yang telah diperbaiki berdasarkan perhitungan data pengisian angket dengan skor rata-rata 3,5 dengan kriteria sangat layak. Berdasarkan validasi ahli bahasa, multimedia interaktif berbasis pendekatan saintifik pada materi bangun datar diperoleh hasil kelayakan dari data pengisian oleh validator bahasa menunjukkan bahwa draf 1 multimedia interaktif berbasis pendekatan saintifik yang telah diperbaiki berdasarkan perhitungan dan pengisian angket dengan skor rata-rata 3,0 dengan kriteria layak. Pedoman penentuan kategori kriteria kelayakan multimedia interaktif berbasis pendekatan saintifik pada materi bangun datar dapat dilihat pada tabel berikut ini.

Tabel 1. Pedoman Tingkat Kelayakan

\begin{tabular}{cc}
\hline Interval Rerata Skor & Kriteria \\
\hline$x>3,4$ & Sangat Valid \\
\hline $2,9-3,4$ & Valid \\
\hline $2,3-2,8$ & Cukup Valid \\
\hline $1,7-2,2$ & Kurang Valid \\
\hline$x \leq 1,6$ & TidakValid \\
\hline
\end{tabular}

Sumber : Adaptasi Widoyoko dalam Yuliana (2017:63) 
Berdasarkan keseluruhan penilaian kelayakan multimedia interaktif dari tiga validator yaitu validator bahasa, validator materi dan validator media dengan skor rata-rata keseluruhan yang dapat dilihat sebagai berikut:

Tabel 2. Persentase Penilaian Seluruh Ahli

\begin{tabular}{cccccc}
\hline No & \multicolumn{1}{c}{ Validator } & $\begin{array}{c}\text { Jumlah butir } \\
\text { pernyataan }\end{array}$ & $\begin{array}{c}\text { Skor yang } \\
\text { diperoleh }\end{array}$ & $\begin{array}{c}\text { Rata-rata } \\
\text { skor }\end{array}$ & Kriteria \\
\hline 1. & Dr. Rusmana Dewi, M.Pd & 7 & 21 & 3 & Layak \\
\hline 2. & Leo Charli, M.Pd. & 12 & 43 & 3,5 & $\begin{array}{c}\text { Sangat } \\
\text { layak }\end{array}$ \\
\hline 3. & Suartini, S.Pd. & 11 & 35 & 3,18 & Layak \\
\hline & Total & $\mathbf{3 0}$ & $\mathbf{9 9}$ & $\mathbf{3 , 3}$ & Layak
\end{tabular}

Sumber: Hasil pengolahan data primer penelitian (2021)

Analisis kelayakan berdasarkan data pengisisan angket oleh ketiga validator menunjukan bahwa prototipe pertama multimedia interaktif yang telah diperbaiki berdasarkan perhitungan data pengisian angket dengan skor rata-rata 3,3 dengan kategori layak. Pelaksanaan uji kegunaan kelompok kecil dilaksanakan pada tanggal 2 Mei 2020 yang terdiri dari 9 siswa dengan kemampuan tinggi, sedang, dan rendah yang dipilih sesuai saran ibu Maisaroh, S.Pd. Hasil penilaian angket pada kelompok kecil dapat dilihat pada tabel di bawah ini:

Tabel 3. Hasil Angket Evaluasi Kelompok Kecil

\begin{tabular}{|c|c|c|c|}
\hline No & Pernyataan & $\begin{array}{c}\text { Nilai } \\
\text { Maksimum }\end{array}$ & $\begin{array}{l}\text { Skor yang } \\
\text { Diperoleh }\end{array}$ \\
\hline 1. & Multimedia interaktif mudah digunakan. & 36 & 27 \\
\hline 2. & $\begin{array}{l}\text { Petunjuk dalam menggunakan multimedia } \\
\text { jelas, sehingga memudahkan } \\
\text { menggunakannya. }\end{array}$ & 36 & 24 \\
\hline 3. & $\begin{array}{l}\text { Penggunaan multimedia interaktif membuat saya merasa } \\
\text { senang. }\end{array}$ & 36 & 31 \\
\hline 4. & $\begin{array}{l}\text { Penggunaan multimedia interaktif membuat saya merasa } \\
\text { tidak bosan. }\end{array}$ & 36 & 28 \\
\hline 5. & $\begin{array}{l}\text { Penggunaan multimedia interaktif membuat saya } \\
\text { bersemangat dan termotivasi untuk belajar setelah } \\
\text { menggunakannya. }\end{array}$ & 36 & 26 \\
\hline & $\begin{array}{l}\text { Multimedia interaktif memudahkan siswa dalam } \\
\text { memahami materi yang disampaikan. }\end{array}$ & 36 & 27 \\
\hline 7. & $\begin{array}{l}\text { Penggunaan multimedia interaktif membuat saya tertarik } \\
\text { jika belajar menggunakan multimedia interaktif ini. }\end{array}$ & 36 & 28 \\
\hline & $\begin{array}{l}\text { Tampilan pada multimedia interaktif sangat menarik } \\
\text { perhatian saya. }\end{array}$ & 36 & 30 \\
\hline 9. & Ingin memiliki multimedia interaktif ini. & 36 & 23 \\
\hline 10. & $\begin{array}{l}\text { Multimedia interaktif ditampilannya terdapat benda- } \\
\text { benda sekitar yang berhubungan dengan materi bangun } \\
\text { datar. }\end{array}$ & 36 & 26 \\
\hline \multicolumn{2}{|r|}{ Jumlah } & 360 & 270 \\
\hline \multicolumn{2}{|c|}{ Rata-rata } & \multicolumn{2}{|c|}{3,0} \\
\hline \multicolumn{2}{|c|}{ Kriteria } & \multicolumn{2}{|c|}{ Mudah digunakan } \\
\hline
\end{tabular}

Sumber: Hasil pengolahan data primer penelitian (2021) 
Berdasarkan hasil perhitungan data angket kegunaan siswa, diperoleh skor rata-rata yaitu 3 dengan kategori mudah digunakaan. Pedoman penentuan kategori kegunaan multimedia interaktif dapat dilihat pada tabel berikut ini.

Tabel 4. Pedoman Penentuan Kategori Kegunaan

\begin{tabular}{cc}
\hline Interval Rerata Skor & Kriteria \\
\hline$x>3,4$ & Sangat mudah \\
\hline $2,9-3,4$ & Mudah \\
\hline $2,3-2,8$ & Cukup mudah \\
\hline $1,7-2,2$ & Kurang mudah \\
\hline$x \leq 1,6$ & Tidak mudah \\
\hline
\end{tabular}

Sumber : Adaptasi Widoyoko dalam Yuliana (2017:63)

Uji kegunaan multimedia interaktif dilakukan dengan ibu Maisaroh, S.Pd. selaku guru wali kelas di kelas IV SD Negeri 5 Lubuklinggau.

Tabel 5. Hasil Seluruh Analisis Kepraktisan Multimedia Interaktif

\begin{tabular}{cccccc}
\hline NO & Penilai & $\begin{array}{c}\text { Jumlah } \\
\text { butir } \\
\text { pernyataan }\end{array}$ & $\begin{array}{c}\text { Skor yang } \\
\text { diperoleh }\end{array}$ & $\begin{array}{c}\text { Rata-rata } \\
\text { Skor }\end{array}$ & Kriteria \\
\hline 1 & Maisaroh, S.Pd. & 10 & 31 & 3,1 & $\begin{array}{c}\text { Mudah } \\
\text { digunakan }\end{array}$ \\
\hline 2 & $\begin{array}{c}\text { 9 Siswa Kelas IV SD } \\
\text { Negeri 5 } \\
\text { Lubuklinggau }\end{array}$ & 90 & 270 & 3 & $\begin{array}{c}\text { Mudah } \\
\text { digunakan }\end{array}$ \\
\hline & Total & 100 & 301 & 3,01 & $\begin{array}{c}\text { Mudah } \\
\text { digunakan }\end{array}$ \\
\hline
\end{tabular}

Sumber: Hasil pengolahan data primer penelitian (2021)

Berdasarkan hasil perhitungan data angket kegunaan siswa dan guru diperoleh rata-rata skor sebesar 3,01 dengan kategori mudah digunakan.

\section{Pembahasan}

Berdasarkan uraian hasil penelitian di atas, diperoleh produk penelitian berupa multimedia interaktif matematika berbasis pendekatan saintifik yang membahas materi bangun datar. Multimedia interaktif berbasis pendekatan saintifik ini dikembangkan dengan menggunakan model pengembangan 4-D yang terdiri dari tahap pendefinisian (define), perancangan (design), dan pengembangan (develop).

Pada tahap pendefinisian (define) ada beberapa hal yang peneliti lakukan yaitu: analisis awal, analisis siswa, analisis tugas, analisis konsep, dan perumusan tujuan pembelajaran. Pada analisis awal diperoleh bahwa kurikulum yang digunakan siswa kelas IV SD Negeri 5 Lubuklinggau adalah kurikulum 2013. Selain itu, guru belum mengembangkan bahan ajar yang dapat membuat siswa menjadi aktif, mandiri dan hanya menggunakan bahan ajar cetak sedangkan media pendukung seperti LCD belum dimaksimalkan. Pada tahap analisis siswa, siswa kelas IV SD Negeri 5 Lubuklinggau rata-rata berusia antara 10-11 tahun, dilihat dari karakteristik anak. Oleh karena itu peneliti memutuskan untuk mengembangkan bahan ajar buku dengan berbentuk media elektronik yang disebut multimedia interaktif berbasis pendekatan saintifik. Pada tahap analisis tugas, peneliti menyusun peta kebutuhan multimedia interaktif yang dapat dijadikan dasar dalam merancang multimedia interaktif berbasis pendekatan saintifik. Pada tahap analisis konsep, peneliti mengidentifikasi konsep-konsep tersebut disusun secara sistematika sehingga membentuk suatu konsep. Konsep materi bangun datar kemudian hasil analisis tugas dan konsep dijadikan dasar dalam merumuskan tujuan pembelajaran. 
Selanjutnya tahap pengembangan model 4-D kedua yaitu tahap perancangan (design). Ada beberapa langkah pada tahap ini yaitu: penyusunan sebagai acuan, pemilihan media, pemilihan format, dan desain awal perangkat pembelajaran. Pada tahap desain ini peneliti merancang media yang akan dikembangkan. Pada tahap ini peneliti merancang multimedia interaktif berbasis pendekatan saintifik dengan storyboard yang telah dirancang untuk desain awal. Pemilihan format isi, materi, dan bahasa yang digunakan dengan jenis tulisan comic sans $M S$ pada media yang akan dikembangkan dan menyajikan materi bangun datar, tampilan desain media ini dibuat semenarik mungkin agar dapat menarik perhatian siswa. Multimedia interaktif dibuat dengan menggunakan aplikasi Macromedia Flash 8. Format Isi pada multimedia interaktif ini terbagi menjadi tiga bagian materi yaitu: persegi, persegi panjang dan segitiga, yang masing-masing menjelaskan indikator yang ingin dicapai. Instrumen berupa angket peserta didik dan guru mengacu pada tingkat kepraktisan media pembelajaran sesuai dengan pendapat (Atmoko dkk., 2017) dari tahap pemilihan media dan pemilihan format akan menjadikan desain awal.

Tahap pengembangan berisi perangkat multimedia interaktif berbasis pendekatan saintifik yang telah selesai dibawa ke validator media, materi dan bahasa untuk diperiksa. Pada validator bahasa peneliti melakukan revisi berupa perbaikan kata dan huruf. Validator materi peneliti melakukan perbaikan isi materi, penambahan contoh, perbaikan menghilangkan lambang yang tidak diperlukan dan menambahkan materi segitiga lebih lengkap. Selanjutnya validator media melakukan perbaikan menu pemilihan materi dan perbaikan warna pada teks multimedia interaktif. Pada tahap mengembangkan multimedia interaktif hal yang dilakukan peneliti adalah membuat multimedia interaktif yang telah dirancang berdasarkan hasil analisis pada tahap pendefinisian (define). Multimedia interaktif disusun dengan menggunakan bahasa Indonesia dan dengan bantuan program aplikasi Macromedia Flash 8. Berdasarkan hasil analisis penilaian kevalidan multimedia interaktif berbasis pendekatan saintifik oleh para ahli mendapatkan skor rata-rata 3,3 yang dikategorikan sangat layak untuk diuji cobakan dengan beberapa perbaikan sesuai saran dari ketiga ahli.

Setelah multimedia interaktif berbasis pendekatan saintifik direvisi selanjutnya diuji cobakan pada guru dan kelompok kecil yang terdiri dari 9 siswa kelas IV SD Negeri 5 Lubuklinggau untuk mengetahui kegunaan multimedia interaktif yang dikembangkan. Pada tahap uji coba kelompok kecil yang terdiri dari 9 siswa hasil analisis data lembar kepraktisan siswa sebanyak 10 pernyataan dengan rata-rata skor sebesar 3 dengan kriteria mudah digunakan. Sedangkan penilaian kepraktisan yang dilakukan oleh guru melalui lembar kepraktisan terdiri dari 10 pernyataan diperoleh rata-rata skor 3,1 dengan kriteria mudah digunakan. Oleh karena itu dapat disimpulkan rata-rata skor kepraktisan yang dinilai oleh siswa dan guru SD Negeri 5 Lubuklinggau adalah 3,01 dengan kriteria mudah digunakan. Berdasarkan uraian di atas, dapat disimpulkan bahwa multimedia interaktif yang dikembangkan dengan pendekatan saintifik pada materi bangun datar siswa kelas IV sekolah dasar tahun pelajaran 2020/2021 dikategorikan telah memiliki kelayakan dan kemudahan dalam penggunaan. 


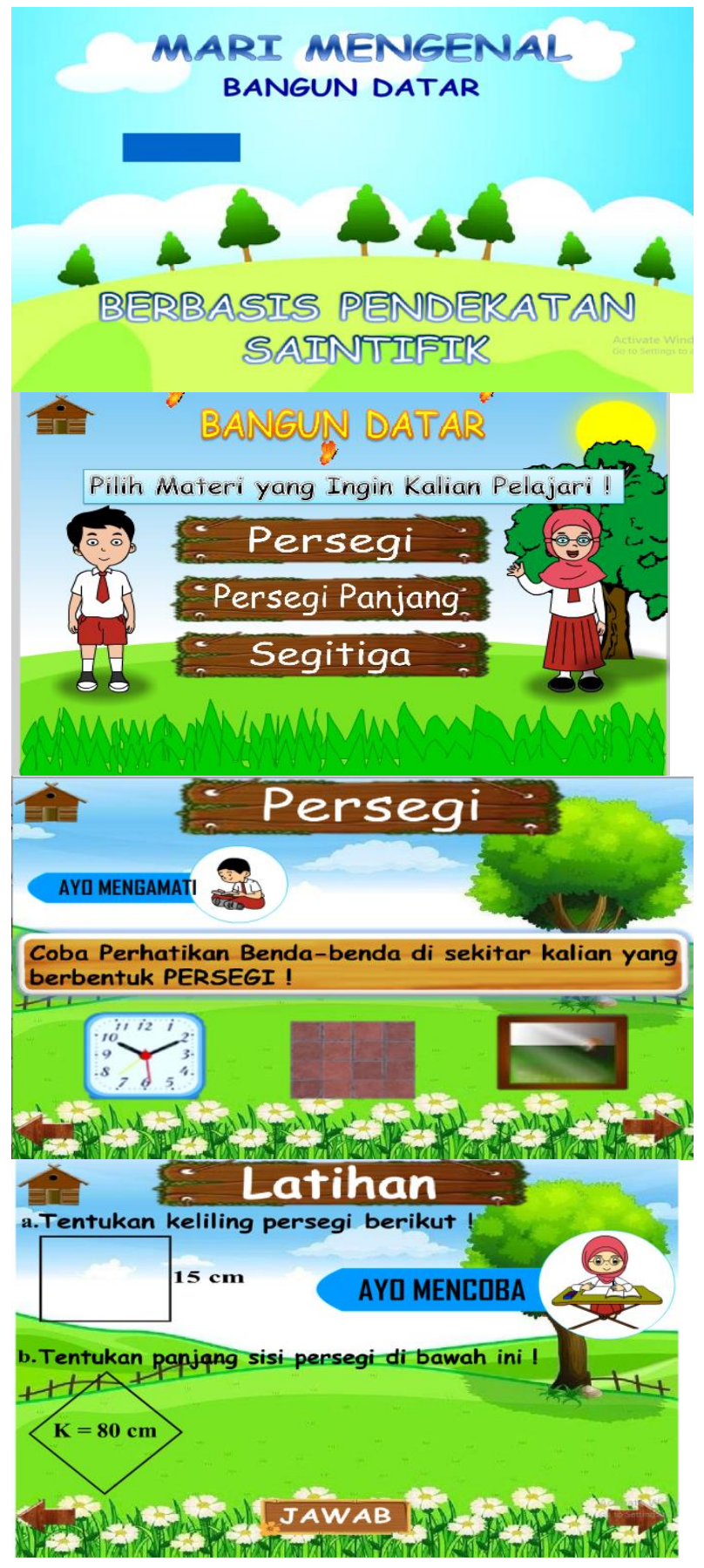




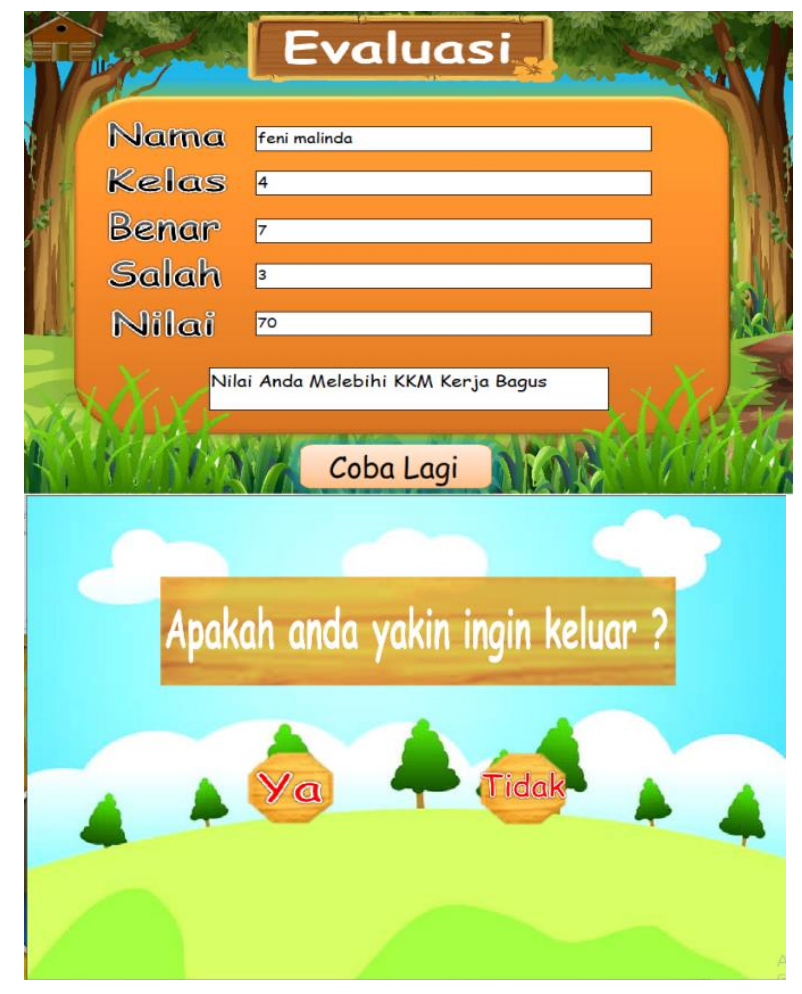

Gambar 1. Screenshoot produk multimedia interaktif berbasis pendekatan saintifik Sumber: dokumen pribadi (2021)

\section{SIMPULAN DAN SARAN.}

\section{Simpulan}

Berdasarkan nilai analisis data tentang pengujian produk multimedia interaktif berbasis pendekatan saintifik yang dikembangkan maka dapat disimpulkan bahwa:

1. Tahap pengembangan dalam penelitian ini menggunakan model pengembangan $4 \mathrm{D}$ yang terdiri atas tahap Pendefinisian (define) terdiri dari analisis awal, analisis siswa, analisis tugas analisis konsep, dan perumusan tujuan pembelajaran. Perancangan (design) terdiri dari pemilihan media, pemilihan format dan desain awal, pada tahap desain awal multimedia interaktif berbasis pendekatan saintifik yaitu pembuatan angket validasi, angket respons siswa dan guru dan pembuatan prototipe pertama. Pengembangan (develop) tahap ini menghasilkan multimedia interaktif berbasis pendekatan saintifik yang sudah di validasi oleh ahli bahasa, materi, dan media.

2. Multimedia interaktif berbasis pendekatan saintifik yang berada pada kategori layak setelah dilakukan revisi sebanyak 2 kali berdasarkan penilaian para ahli bahasa, materi dan media. Kelayakan bahasa memperoleh skor sebesar 3,0 dengan kriteria layak, kelayakan materi memperoleh skor sebesar 3,18 dengan kriteria layak, dan kelayakan media memperoleh skor sebesar 3,5 dengan kriteria sangat layak, sehingga memenuhi kriteria kelayakan dengan memperoleh skor dari semua aspek penilaian validator yaitu 3,3 dengan skor maksimal 4,0 sehingga multimedia interaktif berbasis pendekatan saintifik dapat diklasifikasikan layak.

3. Kepraktisan multimedia interaktif berbasis pendekatan saintifik yang dikembangkan dilihat dari hasil tahap uji coba kelompok kecil (small group) oleh siswa dan guru. Hasil uji coba kelompok kecil diperoleh skor rata-rata sebesar 3 sehingga termasuk dalam klasifikasi praktis dan uji coba kepada guru diperoleh skor rata-rata sebesar 3,1. Dari kedua ahli diperoleh skor rata-rata sebesar 
3,01 dengan skor maksimum kepraktisan 4,0 sehingga multimedia interaktif berbasis pendekatan saintifik berbasis pendekatan saintifik telah memenuhi syarat kegunaan.

\section{Saran}

Beberapa hal yang dapat dijadikan sebagai saran dari penelitian yang telah dilakukan sebagai berikut.

1. Multimedia interaktif yang dikembangkan dalam penelitian ini telah dikategorikan sangat valid dan praktis sehingga dapat dijadikan sebagai salah satu media pembelajaran bagi siswa dan guru sebagai pendukung kegiatan pembelajaran matematika dengan pendekatan saintifik.

2. Pengembangn multimedia interaktif berbasis pendekatan saintifik pada materi bangun datar dapat dijadikan penelitian lanjutan hingga ketahap keefektifan.

\section{DAFTAR PUSTAKA}

Atmoko, S.W., Cahyadi, F., \& Listyarini, I. (2017). Pengembangan Media Utama (Ular Tangga Matematika) dalam Pemecahan Masalah Matematika Materi Luas Keliling Bangun Datar Kelas II SD/MI. Jurnal Pendidikan Guru MI, 4(1), 119-128.

Daryanto \& Karim, S. (2017). Pembelajaran Abad 21. Yogyakarta: PT Gava Media.

Dewi, T. A. (2015). Implementasi Multimedia Interaktif Dalam Pembelajaran Ekonomi di Sekolah. Promosi: Jurnal Program Studi Pendidikan Ekonomi, 3(2). 1-10.

Egok, A.S., \& Hajani, T.J. (2018). Pengembangan Multimedia Interaktif Pada Pembelajaran IPA Bagi Siswa Sekolah Dasar Kota Lubuklinggau. Journal of Elemantary School (JOES). 1(2), 141-157.

Mashuri, S. (2019). Media Pembelajaran Matematika. Yogyakarta: CV Budi Utama.

Mulyono, D., Asmawi, M., \& Nuriah, T. (2018).The Effect of Reciprocal Teaching, Student Facilitator and Explaining and Learning Independence on Mathematical Learning Results by Controlling the Initial Ability of Students. International Electronic Journal of Mathematics Education, 13(3), 199-205.

Musfiqon dan Nurdyansyah. (2015). Pendekatan Pembelajaran Saintifik. Sidoarjo: Nizamia Learning Center.

Rijal, A., dan Egok, A.S. (2019). Pengembangan Bahan Ajar Membaca Berorientasi Strategi PQ4R Di Kelas IV Sekolah Dasar. Jurnal Basicedu, 3(2), 355-371.

Sugiyono.(2017). Metode Penelitian dan Pengembangan Research and Development. Bandung: Alfabeta.

Sumantri, M. dan Syaodih, N. (2009). Perkembangan Peserta Didik. Jakarta: Universitas Terbuka.

Yuliana, R. (2017). Pengembangan Perangkat Pembelajaran Dengan Pendekatan PMRI Pada Materi Bangun Ruang Sisi Lengkung Untuk SMP Kelas IX. Jurnal Pendidikan Matematika-S1, 6(1), 60-67. 